\title{
Developing a Tabletop Game that Stimulates Creativity through Design Thinking and Design Ethnography
}

\author{
Dessy Aliandrina ${ }^{1}$, Firna Pricilla ${ }^{2}$, Hans William ${ }^{3}$, Kadek Feby Anggraeni ${ }^{4}$, Nicholas Augustin Jiemas ${ }^{5}$, \\ Sarah Grace Dwi Anggraheni', Vijjadhammo Anwar ${ }^{7}$ \\ ${ }^{1-7}$ Technopreneurship Department, Faculty of Green Economy and Digital Communication, Surya University, \\ Tangerang, Banten, Indonesia
}

\begin{abstract}
dessy.aliandrina@surya.ac.id (Dessy Aliandrina)1 ${ }^{1}$, firna.pricilla14@student.surya.ac.id (Firna Pricilla) ${ }^{2}$,

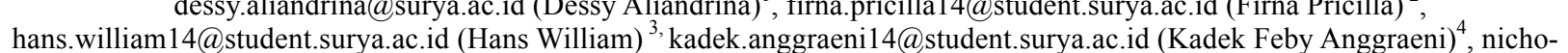
las.jiemas14@student.surya.ac.id (Nicholas Augustin Jiemas) ${ }^{5}$, sarah.anggraheni14@student.surya.ac.id Anggraheni) ${ }^{6}$, vijjadhammo.anwar14@student.surya.ac.id (Vijjadhammo Anwar) ${ }^{7}$

(Sarah Grace Dwi
\end{abstract}

\begin{abstract}
Science and technological advancement in the automation era called the 4th Industrial Revolution requires human to adapt in terms of skill set, particularly creativity, lest they are replaced by the machines. Creativity enables collaboration with the machine, providing opportunity rather than viewing it as a threat. As a country with demographical advantage in 2030, Indonesia's creativity rate is counterintuitive to the fact, thus it has to be improved considering the rise of creativity demand from 10th top skill to the 3rd top skill in 2020. Therefore, this study aims to develop a tabletop game as a learning tool to stimulate creativity by using qualitative ethnographic approach based on Design Thinking and Design Ethnography. Semi-structured interviews with 32 youths aged 17-35 in Tangerang Regency and Tangerang Selatan City were conducted as data collection method. Merged with the ethnographic observation result and literature review, the researchers found out that their needs for a tabletop game are: "fast-paced", "interesting in content and visual", "ergonomics packaging and components", "improved quality of material", "fun", "educative", and "interactive", as well as indirectly delivering moral messages in accordance to the missing values from the millennials. Through ideation, prototyping, and testing stages, tabletop game ideas were being generated, enhanced, and examined in order to meet the needs. The result is Animazzle, an animal characters puzzle-card game of which the features can address the issues. This study concludes that aligning with the process, empathy is the utmost importance of the process because it enables the problem to be properly defined and shapes an urge of continuous development to produce a sound solution.
\end{abstract}

Keywords creativity, empathy, design thinking, design ethnography, tabletop game, millennials

\section{Introduction}

In 2020, World Economic Forum [1] predicted the world will enter the 4th Industrial Revolution, marked by an integration of technologies from physical, digital, and biological scopes. It will result in new trends such as artificial intelligences (AI), robotics, improved internet of things, autonomous vehicles, and many more. In this era, manual labors won't stand long, as WEF also predicted 5.1 million of jobs will be lost across industries. In order to thrive in the so-called revolution, there are particular set of skills required. The top three are sequentially complex problem solving, critical thinking, and creativity. Human creativity will allow collaboration with technology, further creating knowledge in a much faster rate [2] and help solving complexities derived from the technology advancements itself.

However, the increasing needs for creativity is not reflected in Indonesia's creative supply. One of the measure- ment for GII is Creative Outputs; under Innovation Output Sub-Index, and is measured by intangible assets, creative goods and services, and online creativity. Indonesia's score stagnates at least for the past 5 years, scoring $31,41,39,31$, and 25 respectively from 2012-2016. Indonesia, as a country with demographical advantage with a predicted composition of $67,9 \%$ working-age population in 2035 [3], should regard creativity as an emergence of high urgency since it will impact on the economy.

One of the ways to train creativity skills is through the education system. Unfortunately, the current curriculum does not develop the skills that students need in the future. Dananjaya, U. (n.d.) stated that the students tend to memorize the material given by the teacher which discourage them to think creatively [4]. Therefore, the students can be given hands on and minds on activities. Hands on and minds on activities or experiential learning use an active learning concept which enable people to solve problems and create strategies that will nurture and enhance their creativity skills 
[5][6]. Hence, using qualitative ethnography design by applying design thinking, this study aims to define problem and find solution - how to enhance creativity effectively?

\section{Literature Review}

Defining creativity is a matter of perception and therefore relatively immeasurable since there are lots of qualities to judge and determined by domains or fields [7][8][9][10]. As for the consensus, the definition follows the form of an ability in which value in terms that not only it is original [11] and novel, but also appealing and useful at least to a certain extent exists [7][8][12][13].

Creativity can be found in all people to some degree and its mental skills can be developed like the other mental abilities [14][15][16]. Mellou (1996) also stated that creativity can be nurtured once an appropriate creative environment is set [17]. Hirst (2009) and Taggar (2002) stated that environment helps individual learning which in regard to creative-process, corresponds to creative output [18][19]. Mellou (1996) proposed school environment, educational programmes, and teachers as well as their way of teaching as three domains who are responsible in creating environment that may encourage the development of student's creativity [17].

Trostle \& Yawkey (1982) stated that one of the ways to set a creative environment is the exploration [17] or experiential learning. Experiential learning is a particular form of learning from life experience and can be defined as activity that involves students in doing things and thinking about the things they are doing [5]. Experiential learning often contrasted with lecture and classroom learning [20] which is identical to the activity of memorizing the material. Gundry and Kickul (1996) categorized experiential approach in the classroom into the conceptual method and behavioral method [21]. The conceptual method includes mind mapping, pattern-breaking thinking, brainstorming, metaphoric thinking, split brain comparison, mind benders, creative whack-pack, and cross-fertilization while behavioral method consist of music, board games, and visualisation [21].

The involvement and direct experience created through experiential learning allows student to develop empathy, which is positively correlated to creativity [22]. Empathy is a competence that allows us to read people [23]. Empathy is helpful to the extent of understanding and defining a problem [24]. It is often characterized as the ability to "put oneself into another's shoes" or in some way understand another's "state of mind" or emotion [25]. Empathy map can be a tool to build creativity skills [26]. Also, empathy has a role to configure creativity skills. For example, diversity team composition tend to have a culture of sharing knowledge and generate a wider range of original and useful ideas. However, the empathy challenge of working in a diverse team is the ability to accept the perspective of other members in the ideation stage. Thus, empathy plays an important role in diversity teams in order to work effectively [27] and further, enables collaboration between individuals.

\section{Methodology}

The methodology used in this research is qualitative ethnographic approach to understand people's behavior which is influenced by their culture [28]. Design Ethnography aims to understand user through their behavior in which they are engaged [29]. According to anthropologist Margaret Mead, "what people say, what people do, and what people say they do" are entirely different things. Therefore, Design Ethnography will help define the hidden needs and wants of the user. Purposive sampling is selected because the target respondents are youths with age range between 17-35 years old [3] who lived in the regency and city of Tangerang. These locusts were considered to minimize the gap of cultural difference between urban and rural area. The researchers collected data from 32 respondents consisted of 17 respondents from rural area in Tangerang Regency and 15 respondents from urban area in Tangerang Selatan City. Semi-structured interview is used to explore in order to obtain further information about the respondents' knowledge, needs, and wants.

Qualitative ethnography approach is outlined in the design thinking method. Tim Brown of IDEO explained Design Thinking as "a discipline that uses the designer's sensibility and methods to match people's needs with what is technologically feasible and what a viable business strategy can convert into customer value and market opportunity." [30]. Seeking im provement by the iterative process of design thinking method effectively reduces cost and minimize product's failure after it's launched [31].

\subsection{Design Thinking}

Design thinking method has been developed into various models along the time. One of them is the 5-Steps-Process developed and used in Design School of Stanford University [32].

\subsubsection{Empathy}

Empathy is the centerpiece of a human-centered design process [32]. Empathy can help to define the problem to be solved precisely because we are trying to understand people by observing, engaging, watching and listening to them. Observing the way they do things and why will help the researchers to understand what they think and feel. Engaging with people directly will give knowledge about the way they think and the values they hold. Watch and listen is the required way during observing and engaging. In this research, the researchers conduct literature review and brainstorming building empathy to find out the problem and possible solutions that could solve the problem. In addition, the researchers also conduct an ethnographic approach to create a solution that precisely meets the demand. Some of the ways used in design ethnography approach are observing the gesture of the body, the tone when answering, the appearance (more likely to see the color), and the environmental conditions during interviews. The gesture and tone can show how sure the respondents with their own answers. The colors that respondents use, both in terms of clothing and accessories can be reference for researchers to determine what colors 
will be used in product design. The combination of the two methods as already mentioned is addressed to holistically understand the problem before defining and testing the right solution.

\subsubsection{Define}

Define is to make problem statement(s). Semi-structured interviews are used to confirm the problem and possible solutions that have been obtained. The transcriptions of interview were interpreted using open, axial, and selective coding following the framework of Grounded Theory [33]. Open coding to create initial codes by searching the keywords for each respondent's answer. Axial coding identifies relationships among the initial codes and group them into nodes. The final stage of coding is selective coding to identify core code(s). The results of the coding are further developed into a definition of persona as the representation of target audience or the person whose problem is to be solved [34] and planning which consists of mission and strategy.

\subsubsection{Ideation, Prototype and Test}

Ideation will generate the widest possible range of ideas and find the best solution through testing and feedback. Prototype/visualisation of the idea(s) that have been generated is given and tested to the user to gain feedback as insight for refinement. The researchers tested the prototype to 23 youths in Gading Serpong, Tangerang.

\section{Result and Analysis}

\subsection{Empathy and Defining Problem}

Through literature review and brainstorming, the researchers found that Indonesia's creative output score is 25.2 in 2016, which ranks them in 85 th place of 128 countries by Global Innovation Index. It indicates that the level of creativity in Indonesia is still low. Considering in 2020, the World Economic Forum (WEF) predicted that the world will enter the 4th Industrial Revolution and creativity will be the 3rd top skill a worker required to have, thus creativity skills in Indonesia should be improved [1]. Then, the researchers proposed tabletop game as a tool to stimulate creativity. By playing games, players are encouraged to do experimentation, hypothesis testing, and synthesis [35] which are the higher thinking skills [36][37] that further will enhance creativity. Kudrowitz (2013) reviewed how tabletop game can improve creativity [38]. He mentioned that playing allows us to get into the safe environment where we can pretend, imagine, and create, thus making people more creative. It brings new perspectives by making us say and do things we usually don't.

This problem and possible solution were made in the form of questions to be confirmed through interview with the respondents. The interview results with youths in the regency and city of Tangerang were interpreted into open codes and then classified into smaller groups which consist of 15 axial codes, and finally categorized into three core codes: Existing (the qualities needed and already found in current tabletop game), Demand (the qualities needed but still not found in current tabletop game), and Supply (current tabletop game alternatives). The results are further developed into a definition of persona.

Based on the made persona as a product of generalization, we analyze his needs and story to define the mission and strategy of developing the tabletop game. The mission defined as the combination of Demand and Existing codes. Technically, the tabletop game should fulfill the criteria:

- Fast paced

- Interesting content and visual

- Ergonomics packaging and components

- Improved quality of material

\section{- Fun}

- Educative

- Interaction

By looking at the age of the persona (21 years old), the researchers found out that the target audience who lies in the Millennial spectrum of age, are unique compared to the other generations. This uniqueness was measured by Pew Research Centre; technological use is the highest uniqueness of Millennials (24\%) where the value is doubled from Gen X (12\%) [39]. Other Millennials' positive values lost from Gen $\mathrm{X}$ include work ethic and respect. In other words, technological use replaces some positive values from Gen X. Technological value use is also reflected in Millennials' social media uses. Roughly $75 \%$ of Millennials have created at least one social media account in the internet making them the most connected generation and the most susceptible to instant gratification and narcissistic behaviour. These behaviours are harmful to creativity, and further productivity [40].

Through design ethnography, the researchers found that the colors of the clothing and accessories that respondents use are predominantly dark. Dark colors can evoke negative feelings, such as boredom and sadness [41]. Therefore, the researchers used bright colors to make players of the game feel more playful when they play. Bright colors are associated with positive feelings, such as happiness and joy [42].

\subsection{The Iterative Process of Ideation, Prototyping and Testing}

Based on the formulated strategy and literature review about millennial's value, eight game options were proposed as the solution. The ideas chosen have been filtered through some steps where the strategy becomes the guide as well as the limitations for every choice taken. The iterative process of design thinking occurs when ideas were repeatedly generated, translated into prototypes, and then tested (internally and externally) to gain insight or feedback for refinement and to find the best alternative. Afterwards, Animazzle was selected to be developed.
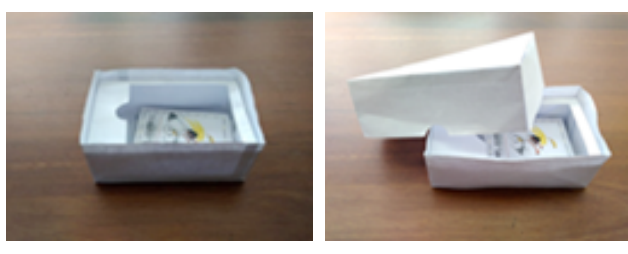

Figure 1. Alpha Prototype 


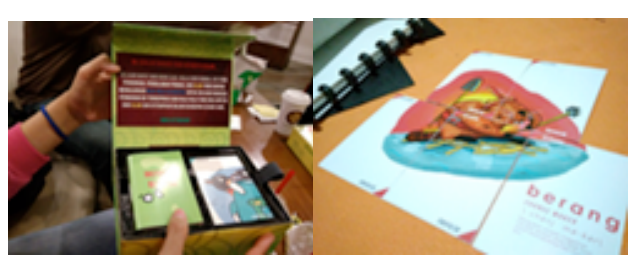

Figure 2. Beta Prototype

The second generation prototype (Beta) is the result of development and realization from the first generation (Alpha). The Beta version consisted of a box with 2 identical deck, 55 characters cards, 25 effect cards, and a rulebook.

The Animazzle game prototype is tested to 23 youths in Gading Serpong, Tangerang. The results are it is acceptable and playable, and perceived as "fun" and "addictive".

\subsection{Animazzle's Features and Gameplay in Stimulating Creativity}

Animazzle is an animal characters puzzle-card game that can be played by 4-6 people with an average time of 16 minutes. Animazzle's mechanism is to collect as many as possible characters by asking or snatching it from opponents. It consists of a deck separated into two piles, which will be played simultaneously during the game. The first pile consists of character cards, while the other consists of effect cards. A character is formed by 5 pieces of character cards. When fit together, they will display an animal representative of values and short story of animal's character written on it. The other pile, the effect cards, is equipped by pictures of animal mimicking the description of the card. Effect cards help players to collect or defend their cards in order to win the game. The feature of this game is as follows: bright colors, arranging an image from scattered pieces, and strategy to use effect card.

Chism (2002) stated that the bright colors of the cards are the physical environments that allow players to see them. The physical environment can have a significant effect on creative output [43]. Solving puzzle-illustrations and building strategy to use Effect cards are skills that could actually train players to use their existing knowledge and in different ways [13]. The values in short stories of every animal's characters was provided to foster empathy, the players could read the animal's characters, notice the feelings of the characters, and try to associate it with their daily life [44]. Overall, these features and content are used to stimulate and enhance creativity.

\section{Conclusion}

Based on our research, it can be concluded that creativity can be stimulated through tabletop game since the usage of Animazzle game as learning tool to develop creativity is acceptable by youths and perceived as positive. Hence, the experiential active learning in playing tabletop game generates creative environment that can effectively enhance creativity skill of individuals.
Additionally, the ultimate conclusion is that the whole development was possible through empathy, or in a simpler sense defined as positioning self in other's perspective. Performing it gives the insight of the problem, and if defined properly, would produce a rather accurate possibilities of solutions. It also shapes an urge of continuous development to solve the problem.

In fact, empathy should be more encouraged since its existence decline amongst the millennials [45][46]. Improving it, on the other hand, should adapt to the milieu of the target (in this case millennials). Hereby, a praise to the statement "Playing is the highest form of research" [47].

This research is limited to developing product and testing its user acceptance. Further research is needed to measure its impact on individual's creativity.

\section{REFERENCES}

[1] World Economic Forum (WEF). (2016). The future of jobs. Geneva: WEF.

[2] Wilson, H. J., Alter, A. E., \& Mulani, N. (2016). Accenture outlook machine reengineering. Retrieved from Accenture: https://www.accenture.com/t20160727T035918_w_/us-en /_acnmedia/Accenture/Conversion-Assets/Outlook/Docume $\overline{n t s} / 2 /$ Accenture-Outlook-Machine-Reengineering.pdf

[3] BPS - Statistics Indonesia. (2013). Indonesian population projection 2010-2035. Retrieved from Kementrian PPN/Bappenas:

https://www.bappenas.go.id/files/5413/9148/4109/Proyeksi Penduduk_Indonesia_2010-2035.pdf

[4] Sidharta, J. (2016, August 23). How Indonesians go to school to memorize, and then forget. Retrieved from Global Indonesian Voices: http://www.globalindonesianvoices.com/27573/how-indones ians-go-to-school-to-memorize-and-then-forget/

[5] Rebecca Winthrop, E. M. (2016). Innovation and technology to accelerate progress in education. Center for Universal Education at Brookings.

[6] Afida Ayob, A. H. (2010). Nurturing creativity and innovative thinking through experiential. Procedia Social and Behavioral Sciences 18 (2011) 247-254.

[7] Kaufman, J. C., \& Baer, J. (2002). Could Steven Spielberg manage the Yankees?: Creative thinking in different domains. Korean Journal of Thinking and Problem Solving, 12(2), $5-14$.

[8] Hennessey, B.A., \& Amabile, T.M. (2010). Creativity. Annual Review of Psychology, 61, 569-598.

[9] Bhasin, H. (2011). Implementation of artificial creativity: redefining creativity. International Journal of Computer Applications, 28(11).

[10] Bhasin, H. (2011). Study of factors affecting artificial creativity. IJCST, 2(2).

[11] Kanematsu, H., \& Dana, M. (2016). STEM and ICT education in intelligent environments. Springer.

[12] Guilford, J. P. (1950). Creativity. American Psychologist, 5, 444-454.

[13] Safertzi, E. (2000). Creativity. Innoregio. 
[14] Torrance, E. (1972). Can we teach children to think creatively? The Journal of Creative Behavior, 6(2), 114-143.

[15] Torrance, E. P. (1987). Teaching for creativity. Frontiers of creativity research: Beyond the basics, 189, 215.

[16] Meyers, B. G. (1982). Developing creative thinking through experiential learning. Developments in Business Simulation \& Experiential Exercises, Volume 9.

[17] Eleni Mellou (1996). Can creativity be nurtured in young children? Early Child Development and Care, 119:1, 119-130, DOI: 10.1080/0300443961190109

[18] Amabile, T. M., \& Pillemer, J. (2012). Perspectives on the social psychology of creativity. The Journal of Creative Behavior, 46(1), 3-15.

[19] Amabile, T. M. (1983). The social psychology of creativity: a componential conceptualization. Journal of Personality and Social Psychology, 1983, Vol. 45, No. 2, 357-376.

[20] Kolb, D. A. (2015). Experiential learning. Pearson Education, Inc.

[21] Gundry, L. K., \& Kickul, J. R. (1996). Flights of imagination: fostering creativity through experiential learning. SAGEPUB: SIMULATION \& GAMING, Vol. 27 No. 3, September.

[22] Alfred F. Carlozzi, Kay S. Bull, Gregory T. Eells \& John D. Hurlburt. (1995). Empathy as related to creativity, dogmatism, and expressiveness. The Journal of Psychology: Interdisciplinary and Applied. 129:4, 365-373, DOI: $10.1080 / 00223980.1995 .9914974$

[23] McKee, A. (2015). Empathy is key to a great meeting. Harvard Business b Review.

[24] Wakefield, J. F. (1991). Problem finding and empathy in art. Paper presented at the Henry B. and Jocelyn Wallace National Research Symposium on Talent Development (Iowa City, IA, May 16, 1991).

[25] V, I. F. (2008). Empathy and emotional intelligence: What is it really about? International Journal of Caring Sciences Vol 1 Issue 3.

[26] Kelley, T. K. (2013). Three creativity challenges from IDEO's leaders. Harvard Business Review.

[27] Chamorro-Premuzic, T. (2017). Does diversity actually increase creativity? Harvard Business Review.

[28] DTI UK. (2004). Innovation through people-centred design.

[29] Insitu. (2016). What is design ethnography? INSITU.

[30] Brown, T. (2008). Design thinking. Retrieved from Harvard Business Review: https://hbr.org/2008/06/design-thinking

[31] Olsen, N. V. (2014). Design thinking and food innovation.

[32] d.school Stanford. (2010). An introduction to design thinking process guide. Retrieved from https://dschool-old.stanford.edu/sandbox/groups/designresou rces/wiki/36873/attachments/74b3d/ModeGuideBOOTCAM P2010L.pdf?sessionID=573efa71aea50503341224491c862e $32 \mathrm{f} 5 \mathrm{edc} 0 \mathrm{a} 9$

[33] Douglas, D. (2003). Inductive theory generation: A grounded approach to business inquiry.

[34] Blomkvist, S. (2002). Persona - an overview.

[35] Schaller, D. (2005). What makes a learning game? Available online: http://www.eduweb.com/schaller-games.pdf
[36] Bloom, B.S. (Ed.), Engelhart, M.D., Furst, E.J., Hill, W.H., \& Krathwohl, D.R. (1956). Taxonomy of educational objectives: The classification of educational goals. Handbook 1: Cognitive domain. New York: David McKay.

[37] Anderson, L.W. (Ed.), Krathwohl, D.R. (Ed.), Airasian, P.W., Cruikshank, K.A., Mayer, R.E., Pintrich, P.R., Raths, J., \& Wittrock, M.C. (2001). A taxonomy for learning, teaching, and assessing: A revision of Bloom's Taxonomy of Educational Objectives (Complete edition). New York: Longman.

[38] Kudrowitz, B. How board games can help us be innovative.

[39] Pew Research Center (2010). Millennials: a portrait of generation next.

[40] Anderson, J. Q. (2012). Millennials will benefit and suffer due to their hyperconnected lives. Pew Research Center's Internet \& American Life Project.

[41] Hulshof, B. (2013). The Influence of Colour and Scent on People's Mood and Cognitive Performance in Meeting Rooms. University of Twente.

[42] Kaya, N. (2004). Relationship between color and emotion: a study of college students. The University of Georgia.

[43] Shinberg, K. L. (2011). Physical environments for creativity and design. In S. A. Gemmill, Creativity and Design in Technology \& Engineering Education (p. 212). Council on Technology Teacher Education.

[44] Brittin, D. S. (n.d.) Teaching empathy through read aloud and role-play.

[45] Bergman, S. (2011). Millennials, narcissism, and social networking: What narcissists do on social. Personality and Individual Differences, 706-711.

[46] Stein, J. (2013). TIME. Millennials: The me me me generation.

[47] Scarfe, N. V. (1962). Play is education. 